DOROTA STASIAK

Instytut Nauk Politycznych UW

\title{
Karl Popper, czyli przypisy do Platona raz jeszcze
}

Namysł nad polityką stanowi nałóg ludzkości - w każdej epoce rodzą się idee, teorie i przeświadczenia, które rzucają wyzwanie „przesądom” minionych lat. Choć każdy okres chciałby się sycić monopolem na prawdę i własnym nowatorstwem, niezmiennym punktem odniesienia pozostaje starożytność. W gronie filozofów, których poglądy przywoływane są najczęściej, miejsce szczególne zajmuje Platon. Alfred Whitehead nie zawahał się nawet stwierdzić, że w gruncie rzeczy cała filozofia to tylko przypisy do Platona ${ }^{1}$. Jednym $\mathrm{z}$ dwudziestowiecznych intelektualistów, który zdecydował się na opatrzenie filozofii Platona autorskimi przypisami był Karl R. Popper, autor pracy Spoleczeństwo otwarte i jego wrogowie, „przedstawiającej Platona, Hegla i Marksa jako propagatorów zamkniętego monizmu, odrzucających zarówno aktualny, jak i metodologiczny indywidualizm"2.

Popper podjął się próby krytycznego odczytania Platona w okresie, gdy świat zmagał się z totalitaryzmem, a najtęższe umysły zadawały pytania o jego źródła. Ogólnie rzecz biorąc, amerykańscy i angielscy myśliciele - podobnie jak uciekinierzy z hitlerowskiej Europy - z dumą utożsamiali się z kulturą ateńską przeciwstawianą niemieckiemu militaryzmowi, który kojarzono ze starożytną Spartą czy Macedonią ${ }^{3}$. Tymczasem Popper, który na kilka miesięcy przed zajęciem jego ojczystej Austrii przez Niemcy wyjechał

A. N. Whitehead, Process and Reality, New York 1929, s. 63.

S. Filipowicz, Historia myśli polityczno-prawnej, Gdańsk 2001, s. 360.

J. T. Roberts, Athens on Trial. The Antidemocratic Tradition in Western Thought, Princeton-New Jersey 1994, s. 295. 
do Nowej Zelandii i obserwował wojnę z dystansu, rzucił wyzwanie rozpowszechnionemu przekonaniu, że totalitaryzm wiąże się z odejściem od dziedzictwa Platona. Powodowany „poczuciem odpowiedzialności, jaka spoczywa na filozofie - odpowiadał na pytania o losy świata po II wojnie światowej, sięgając ku starożytnym, platońskim i arystotelesowskim źródłom totalitaryzmu"4.

W 1945 roku Popper napisał dwie prace, które weszły do kanonu rozważań z kręgu filozofii polityki. Jak sam stwierdza: „Nędza historycyzmu i Społeczeństwo otwarte były moim udziałem w wojnie. Sądziłem, że po raz kolejny centralnym problemem stanie się wolność, zwłaszcza w obliczu odzyskującego wpływy marksizmu i planowania na wielką skalę (...). Książki te były więc obroną wolności przed ideami totalitarnymi i autorytarnymi oraz ostrzeżeniem przed niebezpieczeństwami historycystycznych przesądów" ${ }^{5}$ (historycyzm w rozumieniu Poppera oznaczał przekonanie o istnieniu niezmiennych praw historycznego rozwoju). Rozważania Poppera miały być antidotum na zapędy chcące zmieść dotychczasowy porządek w imię ucieleśniania idealnego wzorca. Filozof podkreślał bowiem, że niezależnie od tego, dokąd chcielibyśmy pójść, musimy wyruszyć stąd, gdzie jeszcze jesteśmy. Należałoby więc wyzbyć się plagi projektowania ostatecznych, jedynie słusznych i pożądanych wizji przyszłości. Punktem wyjścia powinna być konkretna rzeczywistość, w jakiej żyjemy ${ }^{6}$.

Reakcje, jakie wywołała publikacja prac Poppera, pozwalają stwierdzić, że nie tylko wziął on udział $\mathrm{w}$ wojnie, lecz jednocześnie rozpętał nową. Popper pragnął pobudzić do refleksji nad zakusami faszyzmu, który stanowił zagrożenie wolności i racjonalności oraz zaproponować rozwiązania mogące uchronić społeczeństwa przed uleganiem ideologiom totalitarnym. Dążąc do tego celu, wypracował perspektywę odkrywającą podobieństwa pomiędzy wszystkimi formami społeczeństwa zamkniętego - trybalizmem, faszyzmem, komunizmem czy fundamentalizmem religijnym ${ }^{7}$. Wywołało to burze komentarzy i dyskusji. Popper atakował bowiem platonizm, „którego wpływ na system brytyjskiej edukacji był niebagatelny, oraz marksizm, z którym sympatyzowali liczni intelektualiści"8. Kiedy podczas II wojny światowej Po-

4 A. Chmielewski, Społeczeństwo otwarte czy wspólnota. Filozoficzne i moralne podstawy nowoczesnego liberalizmu oraz jego krytyka we wspótczesnej filozofii społecznej, Wrocław 2001, s. 49.

K. Popper, Nieustanne poszukiwania. Autobiografia intelektualna, przeł. A. Chmielewski, Kraków 1997, s. 159.

6 B. Magee, What Use is Popper to a Practical Politician? w: Popper's Open Society After 50 Years. The Continuing Relevance of Karl Popper, I. Jarvie, S. Palong (ed.), London-New York 1999, s. 146158.

I. Jarvie, S. Pralong, Introduction w: Popper's Open Society..., s. 3.

Tamże, s. 4. 
pper zabiegał o wydanie książki Społeczeństwo otwarte i jego wrogowie, ,jeden z opiniodawców odrzucił tę propozycję wydawniczą, ponieważ uznał, że Popper wykazał się «brakiem szacunku dla Arystotelesa»". Czy zapomniał wspomnieć o Platonie?

O tym, jakie poruszenie wywołały poglądy Poppera i jego obrazoburczy atak na główny autorytet świata antycznego, niech świadczy oburzenie dwóch innych znaczących emigrantów z Europy - Leo Straussa i Erica Voegelina. $\mathrm{W}$ ich korespondencji napotkać można uwagi na temat twórczości Poppera („,najbardziej rozmyty, bezduszny pozytywizm”), jak i samego autora (,prymitywny ideologiczny awanturnik”, „bezczelny, nieokrzesany”) ${ }^{10}$. Niesmak Straussa i Voegelina należy tłumaczyć faktem, że uważali się oni za filozofów polityki, a klasyczna myśl grecka stanowiła dla nich źródło inspiracji i wzorzec. Byli ponadto zdania, że współczesna nauka społeczna, pozbawiona filozoficznej substancji, nie wyjaśnia powstania narodowego socjalizmu, a w gruncie rzeczy sama może stanowić część tego problemu ${ }^{11}$. Poglądy Poppera, przedstawiającego tak drogiego im Platona jako archetyp utopisty, który w imię cnoty dopuszcza stosowanie przymusu, nie mogły im przypaść do gustu.

Mimo fali krytyki, z jaką początkowo spotkała się popperowska interpretacja Platona, z czasem, zdaniem niektórych, stała się ona wykładnią obowiązującą. Jak nie bez żalu konstatuje Steven Smith, w drugiej połowie XX wieku Platona uznaje się za zażartego wroga liberalizmu i „społeczeństwa otwartego". Przedstawiana przez niego wizja zamkniętego systemu stanowego, cenzura poezji i literatury, radykalne środki służące wyeliminowaniu rodziny i własności prywatnej, powierzenie władzy wszechwiedzącym i wszechpotężnym filozofom, nawet najbardziej przyjaznym czytelnikom wydadzą się sprzeczne z liberalną wiarą w wolność myśli i wyrażania poglądów, szeroką sferą społeczeństwa obywatelskiego i życia prywatnego ${ }^{12}$. Na domiar złego, Platon uważa, że Formy i Idee mogą stanowić oparcie dla absolutnej pewności co do znaczenia terminów takich, jak sprawiedliwość, piękno i dobro, co stoi w wyraźnej sprzeczności z otwartym, sceptycznym i dociekliwym duchem filozofii liberalnej ${ }^{13}$.

\footnotetext{
A. Chmielewski, dz. cyt., s. 49.

Faith and Political Philosophy. The Correspondence Between Leo Strauss and Eric Voegelin 19341964, P. Emberly, B. Cooper (ed.), University Park 1993, s. 67.

I. Jarvie, S. Pralong, dz. cyt., s. 6.

12 S. B. Smith, Leo Strauss's Platonic Liberalism, „Political Theory”, vol. 28, no. 6, 2000, s. 787809.
}

13 Tamże, s. 787. 
To właśnie przyjęcie specyficznej optyki liberalnej sprawia, że Platon może jawić się jako wróg wolności. Wystarczy przyjrzeć się kategoriom, w jakich uczeń Sokratesa ujmował świat. Jak zauważa Jerzy Szacki, Platona „zajmowała nie wyzwolona z dawnych więzów jednostka ludzka, lecz trwała wspólnota, która ma solidniejsze podstawy niż wola jednostek i umowy między nimi, a także cel wyższy niż zapewnienie szczęścia jednostkom"14. Sprzeczność z liberalnym katalogiem wartości, w którym jednostka jest kategorią naczelną, nie jest rzecz jasna „winą” wyłącznie Platona. Dla Greków dobre życie wiązało się bowiem z pomyślnością wspólnoty, a życie poza nią było nie do pomyślenia. Mogli pozwolić sobie na nie jedynie bogowie lub idiotes. „Owo zrośnięcie się jednostki ze wspólnotą powodowało, że coś takiego, jak wolność osobista w nowoczesnym tego słowa znaczeniu, czy też tym bardziej - zespół naturalnych jednostkowych uprawnień, tak typowy dla nowożytnych (dokładniej - liberalnych) idei dobrego życia, było Grekom nieznane"15.

Platońskie państwo idealne, którego celem było dążenie do sprawiedliwości, miało stanowić swoistą całość. Jak podkreśla Szacki, w myśli Platona mamy do czynienia z jednym z pierwszych zastosowań organicystycznej metafory społeczeństwa: „Przedstawia ona społeczeństwo (państwo) jako całość, złożoną z większej lub mniejszej liczby różniących się od siebie części, które wypełniają w jej obrębie odmienne funkcje i są z tego powodu równie niezbędne dla jej sprawnego funkcjonowania: żadna $\mathrm{z}$ nich nie może zostać usunięta lub zasadniczo zmieniona bez szkody dla całości i żadna nie może się usamodzielnić, nie narażając na szwank całego organizmu i tym samym, wszystkich pozostałych części”"16.

Sprawiedliwość w polis miała być wzorowana na sprawiedliwości w jednostce ludzkiej, która istnieje, gdy trzy elementy duszy: rozumny, popędliwy i pożądliwy, znajdują się w równowadze. Trzem wymienionym pierwiastkom duszy odpowiadają trzy rodzaje ludzi: kochający mądrość, ceniący przede wszystkim sławę i odnoszenie zwycięstw oraz rozmiłowani $\mathrm{w}$ dobrach materialnych ${ }^{17}$. Stąd też miały istnieć w państwie trzy podstawowe stany - rządzący, wojownicy i rzemieślnicy (,w zakresie tych trzech łączenie zawodów w jednym ręku i zmiana jest największą szkodą dla państwa i najsłuszniej powinna się nazywać szkodnictwem"18).

\footnotetext{
J. Szacki, Historia myśli socjologicznej, Warszawa 2005, s. 24.

A. Szahaj, M. N. Jakubowski, Filozofia polityki, Warszawa 2005, s. 13-14.

J. Szacki, dz. cyt., s. 24-25.

Platon, Państwo, 581c, przeł. W. Witwicki, s. 292.

Tamże, 434 b,c, s. 134.
} 
Platońska wizja idealnej polis wiąże się z nauką o istnieniu świata idei - „niezmiennego i trwałego królestwa wzorców, wobec których świat otaczających człowieka rzeczy jest jedynie światem przemijających kopii, ułudy i iluzji”. W idealnym państwie rządzić mieliby zaś najlepsi, czyli filozofowie $^{19}$, ponieważ tylko oni „mogą poznać świat idei dzięki swej umiejętności posługiwania się rozumem i cnotliwemu życiu oddanemu kontemplacji nieprzemijających prawd" ${ }^{20}$. Filozofowie to ludzie o nieprzeciętnych zdolnościach i inteligencji. Uczynili największe postępy na drodze cnoty i poznania prawdy. Na uwagę zasługuje ich gotowość do rezygnacji z własności prywatnej i do służenia dobru wspólnemu. „Nie pragną oni dla siebie władzy, woleliby obcować z najwyższym Dobrem, ale muszą spłacić dług zaciągnięty wobec społeczeństwa, które im umożliwiło zbliżenie się do idei Dobra; mają więc obowiązek zaszczepić w duszach obywateli te wartości i to dobro, które sami poznali”21. Choć przynależność do wyróżnianych przez Platona klas nie była dziedziczna ${ }^{22}$, intelektualny elitaryzm filozofa (,rządzić powinny jednostki najbardziej inteligentne, które ponadto staną się najmądrzejsze, jeśli otrzymają właściwy rodzaj wychowania"23) od zawsze budził wiele kontrowersji $i^{24}$.

Przyglądając się najważniejszym wątkom socjologicznym w myśli Platona, Jerzy Szacki wskazuje na kolejne motywy, które współcześnie wydawać się mogą kontrowersyjne ${ }^{25}$. Jednym z nich jest majątkowe zróżnicowanie społeczeństwa - nierówności społeczne uznawał Platon za jedną z przyczyn rozkładu państwa. Sprawiają one bowiem, że interes części zaczyna górować nad interesem całości. Chcąc uniknąć tego problemu, Platon przedłożył projekt komunizmu ${ }^{26}$. Kolejnym z nich jest ujednostkowienie społeczeństwa. Platon niepokoił się, „że postępująca indywidualizacja stanowi zagrożenie ładu społecznego i w swoim projekcie państwa idealnego przewidział liczne środki uniformizacji jego obywateli w zakresie zarówno ich zachowania się

Tamże, 473 d-e, s. 177.

20 A. Szahaj, M. N. Jakubowski, dz. cyt., s. 18.

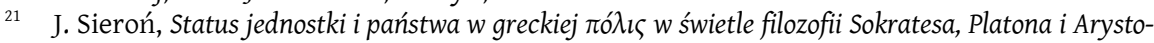
telesa, Katowice 2003, s. 107-108.

22 Por. Platon, Państwo, 369-374, s. 62-69.

23 A. Quinton, Konserwatyzm w: Przewodnik po wspótczesnej filozofii politycznej, R. E. Goodin, F. Pettit (red.), przeł. C. Cieśliński, M. Poręba, Warszawa 2002, s. 348.

24 Przykładowo, Quinton wskazuje na dwie zasadnicze trudności, jakimi obarczona jest ta koncepcja: „pierwsza ma charakter teoretyczny i dotyczy tego, czym właściwie jest mądrość, którą powinni posiadać rządzący. Druga jest praktycznej natury i dotyczy tego, jak rozpoznawać posiadaczy owej mądrości, a następnie wynosić ich do władzy" (A. Quinton, Konserwatyzm... , s. 348).

25 J. Szacki, dz. cyt., s. 25-27.

26 Por. Platon, Państwo, 422e-423a, s. 120-121. 
publicznego, jak i myśli czy uczuć"27. Z tej właśnie przyczyny postulował „drobiazgową kontrolę nad wszystkimi sferami życia jednostek, pozbawiając je prawa do wszelkich ekstrawagancji, te bowiem są zawsze potencjalnym zagrożeniem dla ustalonych zasad ładu społecznego" ${ }^{28}$. W organizmie państwowym miał również istnieć podział pracy przypieczętowujący jedność państwa $^{29}$. Ideałem Platona było bowiem społeczeństwo możliwie najpodobniejsze do jednego człowieka - organizm. Celem była wewnętrzna jedność i należało zwalczać to, co jej zagraża.

Choć interpretacji i reinterpretacji Platona dokonywano wielokrotnie, totalitaryzm II wojny światowej na nowo otworzył dyskusję nad możliwymi konsekwencjami snucia (i realizacji) wizji państwa idealnego. Jednej z odpowiedzi na pytanie o źródła inżynierii społecznej Hitlera i Stalina udzielił Karl Popper, który podniósł rękę na niekwestionowany, zdawać by się mogło, autorytet i dokonał daleko idącej krytyki filozofii Platona. Postawił go w jednym rzędzie z Heglem i Marksem, którym przypisywał główny udział w stworzeniu podwalin totalitaryzmu w nowożytnej Europie ${ }^{30}$. Próba odnalezienia pierwowzoru totalitaryzmu w świecie antycznym była czynem tyleż odważnym, co karkołomnym. Jak podkreśla Stanisław Filipowicz, choć „ideał jedności pojawiał się oczywiście na przestrzeni wieków wielokrotnie i w wielu różnych wcieleniach”, sam totalitaryzm „pozostaje fenomenem historycznym i wszelkie próby retrospektywnego zastosowania pojęcia (...) prowadzą na manowce" ${ }^{31}$. Czy na manowce zawiódł czytelników Społeczeństwa otwartego także Popper, który stwierdził, że „postawa [Platona] jest autorytarna i dyktatorska" i że „nie cierpi jego postawy moralnej” ${ }^{22}$ ?

W przedmowie do wydania drugiego Społeczeństwa otwartego Popper, który na napisanie tej pracy zdecydował się w 1938 roku pod wpływem aneksji Austrii, zauważa: „pisanie przeciągnęło się do roku 1943, to zaś, że przeważająca część książki powstawała w tych trudnych latach, kiedy wynik wojny był niepewny, wyjaśnia dlaczego zawarte w niej niektóre uwagi uderzają dziś mnie samego większą emocjonalnością, ostrością tonu, niż bym sobie tego życzył. Ale nie był to czas na odważanie słów" ${ }^{33}$. Słów istotnie

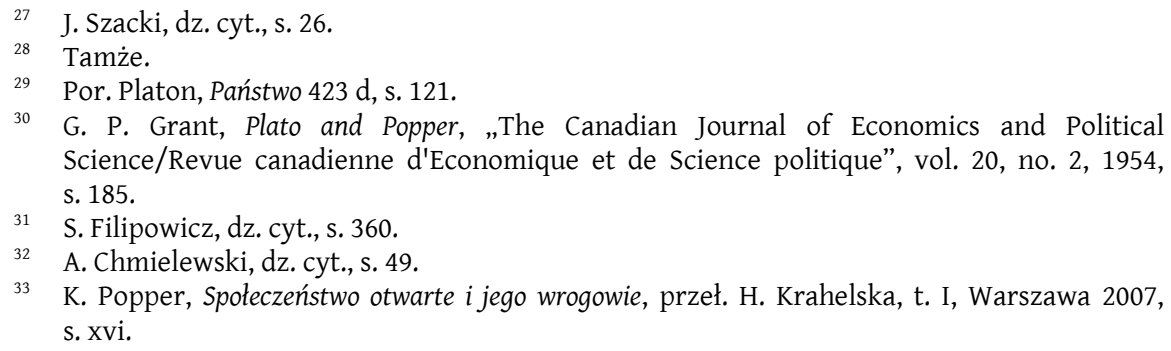

33 K. Popper, Spoteczeństwo otwarte i jego wrogowie, przeł. H. Krahelska, t. I, Warszawa 2007, s. xvi. 
Popper nie ważył. Zbyt silne żywił przekonanie, że „właśnie na Platona trzeba patrzeć bardzo krytycznym okiem, ponieważ powszechne uwielbienie dla tego «boskiego filozofa» ma autentyczną podstawę w jego przytłaczających osiągnięciach intelektualnych" ${ }^{34}$.

Sięgając po pióro, pragnął Popper wykazać, że „cywilizacja nasza nie otrząsnęła się jeszcze z szoku towarzyszącego jej narodzinom, to jest przejściu z plemiennego lub «zamkniętego» społeczeństwa, podporządkowanego siłom magicznym, do społeczeństwa "otwartego», które wyzwala władze krytyczne człowieka” ${ }^{35}$. Kluczowy dla swych rozważań termin „społeczeństwo otwarte” zaproponował Popper ,jako synonim dla niezbyt szczęśliwej nazwy "demokracja»" ${ }^{36}$. Demokrację należałoby według niego tłumaczyć jako rządy ludu, tymczasem Ateńczycy rozumieli pod tym pojęciem takie państwo, „w którym ludzie nie są rządzeni w despotyczny sposób”37. Popper podkreślał również, że „wolność polityczna (...) jest społecznym warunkiem życia ludzi moralnie odpowiedzialnych", a tyrania większości, ludu, nie jest lepsza od żadnej innej tyranii. Społeczeństwo otwarte "cechuje prawo do podejmowania przez jednostki osobistych decyzji, co do swego życia, a także "współzawodnictwo o status społeczny», wiążące się z istnieniem równych szans życiowych oraz otwartych kanałów awansu społecznego. Ideałem filozofa nie jest „ani rząd większości, ani «absolutna wolność», lecz samorząd" 38 .

Popper podjął również zagadnienie zastosowania „krytycznych i racjonalnych metod naukowych do problemów społeczeństwa otwartego". Krytykował także historycystyczne filozofie społeczne za negatywny stosunek do możliwości demokratycznych reform. Popper opowiadał się za „cząstkową inżynierią społeczną, tzn. za koniecznością eliminowania konkretnego zła z życia społecznego, a przeciwko próbom dążenia do realizacji jakiegoś całościowego Dobra"39.

Swoje zainteresowanie metodami nauk społecznych tłumaczy Popper „powstaniem totalitaryzmu oraz klęską, jaką poniosły nauki społeczne i filozofie społeczne próbujące go zrozumieć" ${ }^{40}$. Filozof boleje nad tym, że wiele wykształconych i inteligentnych osób wysnuwa tezy o nieuchronności totalitaryzmu. Ich zdaniem demokracja to jedna z form rządzenia, która obumiera

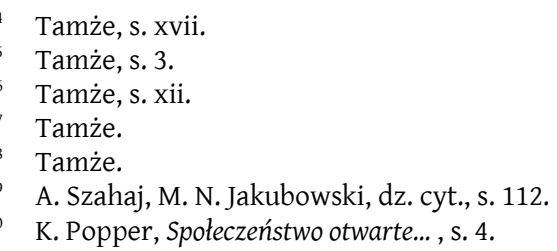


w toku ewolucji, a chcąc walczyć z totalitaryzmem trzeba sięgać po jego metody. Głoszą także nieuchronność kolektywnego planowania w gospodarce ${ }^{41}$. Rozdrażniony owymi proroctwami Popper zastanawia się, czy ,jakakolwiek nauka społeczna ma dane po temu, by wysuwać tak śmiałe proroctwa historyczne”, czy może tworzy wyłącznie „nieodpowiedzialne przepowiednie wróżbity”. Po namyśle dochodzi do przekonania, że „takie śmiałe proroctwa historyczne wykraczają poza zakres metody naukowej. Przyszłość zależy od nas samych, my zaś nie zależymy od żadnej konieczności historycznej" ${ }^{42}$. Kowalami własnego losu możemy zostać tylko wówczas, gdy „przestaniemy pozować na jego proroków" ${ }^{\prime 3}$. Popper sprzeciwiał się wierze w nieuchronność pewnych zdarzeń, ponieważ osłabia ona poczucie odpowiedzialności, które zastępowane jest podporządkowaniem osobowym lub anonimowym siłom rządzącym społeczeństwem. Cały znienawidzony przez siebie nurt historycyzmu interpretował jako reakcję przeciw uciążliwości cywilizacji i odpowiedzialności, jaka na nas spoczywa.

Za podstawowe elementy platońskiego programu politycznego uznał Popper ścisły podział klasowy oraz utożsamienie losu państwa z losem klasy rządzącej - „skierowanie zainteresowania wyłącznie na tę klasę i jej jedność; służące tej jedności sztywne prawa wychowania i wykształcenia klasy rządzącej oraz ścisła kontrola i kolektywizacja interesów jej członków"44. W połączeniu z monopolem klasy rządzącej na wykształcenie wojskowe, cenzurą i propagandą zmierzającą do ujednolicenia umysłów rządzących oraz postulatem samowystarczalności państwa tworzą one, zdaniem Poppera, program iście totalitarny. Społeczeństwo zamknięte charakteryzuje się bowiem „ograniczeniem wolności jednostek, kuratelą władzy państwowej sprawowanej nad jednostkami, wszechobecnością regulacji prawnych krępujących swobodę ich działania, kontrolą wypowiedzi (cenzurą) oraz naciskami na przyjęcie jakiejś jednej doktryny światopoglądowej jako Prawdziwej” ${ }^{45}$.

Mimo, że deklarowanym celem doktryny Platona było szczęście obywateli oraz rządy oparte na sprawiedliwości, Popper nie uznaje jej moralnej wyższości nad totalitaryzmem. Platońska idea sprawiedliwości zasadza się na tym, co dobre dla idealnego państwa, tj. (jak twierdzi Popper) „powstrzymywaniu wszelkich zmian drogą sztywnego podziału klas poprzez rządy klasowe" ${ }^{46}$. Popper zauważa, że platońskie rozumienie sprawiedliwości odbiega

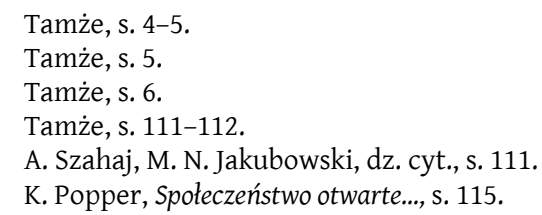


od raczej egalitarnych wyobrażeń na jej temat (Platon uznaje przywileje klasowe, sprawiedliwość zaś widzi jako właściwość państwa jako całości). Zastanawiając, się, dlaczego w Państwie Platon twierdzi, że sprawiedliwość to brak równości, Popper dopuszcza jedną odpowiedź: „chciał zrobić propagandę swemu totalitarnemu państwu, wmawiając ludziom, że jest ono sprawiedliwe" ${ }^{\prime \prime}$.

Innym zarzutem wobec Platona była chęć „zaprojektowania teorii sprawiedliwości, w której nie ma miejsca na egalitaryzm, albowiem władzę powierza się jakiejś wybranej grupie ludzi (...) posiadającej jakoby patent na znajomość Prawdy"48. Popper uznaje to za wyraz pogardy dla ludzi, braku poszanowania jednostkowych wolności oraz „zgubnej tendencji do budowy państwa ideologicznego, kierującego się jakąś państwową doktryną moralną"49.

Kolejnym wątkiem myśli Platona, która według Poppera nosi znamiona totalitaryzmu, jest fakt, że Platona interesuje wyłącznie kolektyw, a sprawiedliwość uznaje za „zdrowie, jedność i stabilność zbiorowości” ${ }^{50}$. Platon tworzy wizje społeczeństwa organicznego, w którym jednostki są podporządkowane całości. „Państwo organiczne jest wyrazem wiary w możliwość realizacji jakiegoś jednego, właściwego wzoru życia politycznego i społecznego, projektu całościowej organizacji społecznej, gospodarczej i politycznej, wreszcie - powrotu pierwotnego trybalizmu, w którym ważna była jedynie wspólnota (plemię), jednostka zaś w ogóle się nie liczyła" ${ }^{51}$. Ponieważ zgodnie z optyką kolektywizmu dobro wspólnoty przeważa nad dobrem jednostki, Popper obawiał się, że troska o poszczególnych ludzi może zaniknąć.

Platon koncentruje się na tym, kto powinien rządzić. Według niego zadanie to należałoby powierzyć „najlepszym”. By dostać się do ich grona, jednostki muszą przejść rozbudowaną edukację, której celem - zdaniem Poppera - jest nie nauka krytycznego myślenia, lecz indoktrynacja ${ }^{52}$. U Platona miłośnik prawdy nie jest jej skromnym poszukiwaczem, lecz dumnym posiadaczem; zbliża się do wszechwiedzy i do wszechmocy. Popper nazywa ideę króla-filozofa „pomnikiem ludzkiej małości”. Stoi jego zdaniem w kon-

47 Tamże, s. 119. Warto nadmienić, że w przeciwieństwie do Poppera, który krytykował Platona za chęć zniszczenia egalitaryzmu i za dążenie do tego, aby nauczyć ludzi, że „sprawiedliwość znaczy nierówność", przeciwne stanowisko obiera w tej kwestii m.in. F. A. Hayek, który staje po stronie Platona, głosząc tezę o fundamentalnej nierówności egalitaryzmu. Por. A. Chmielewski, dz. cyt., s. 151.

48 A. Szahaj, M. N. Jakubowski, dz. cyt., s. 111.

49 Tamże.

$50 \quad$ K. Popper, Spoleczeństwo otwarte..., s. 136.

51 A. Szahaj, M. N. Jakubowski, dz. cyt., 111.

52 K. Popper, Spoleczeństwo otwarte..., s. 169. 
traście do prostoty i humanitaryzmu Sokratesa, który „przestrzegał mężów stanu przed upojeniem się swoją własną mocą, doskonałością i mądrością". Jest to „upadek ze świata ironii, rozumu i prawdomówności do królestwa mądrości Platona, którego magiczne siły wynoszą ponad przeciętnych ludzi, nie jednak tak wysoko, by mógł zrezygnować z kłamstwa"53. Platon pozwalał bowiem rządzącym kłamać dla dobra państwa ${ }^{54}$. Popper ostro komentuje tę praktykę, mówiąc, że „motywem dążenia Platona, by wierzyli w kłamstwa propagandowe, jest nadzieja, że w ten sposób przyda tym kłamstwom siły i zabezpieczy ich skuteczność, umacniając rządy rasy panów i wstrzymując tym samym wszelką zmianę polityczną" ${ }^{55}$.

Choć Popper przyznaje, że Platon mógł dostrzegać rzeczywiste bolączki swych współobywateli, „zalecana przezeń kuracja medycznopolityczna, wysuwająca na czoło powstrzymanie zmiany i powrót do trybalizmu, była fatalną pomyłką"56. Dlaczego? Jak stwierdza Popper, „powstrzymanie zmiany nie leczy. Nie możemy wrócić do rzekomej niewinności i piękna społeczeństwa zamkniętego (...) Z chwilą, gdy zaczynamy polegać na rozumie i posługiwać się władzami krytycznymi, z chwilą, gdy poczuwamy się do odpowiedzialności osobistej, a wraz z nią do odpowiedzialności za postęp wiedzy, nie możemy już wrócić do stanu magii trybalnej. (...) Nie ma powrotu do harmonijnego stanu natury. Jeżeli zawrócimy, to musimy już przejść tę drogę do końca - musimy wrócić do stanu zezwierzęcenia" ${ }^{57}$.

Wiele osób nie godzi się na popperowską interpretację Platona. Liczni obrońcy starożytnego filozofa uważają, że ludzie pokroju Poppera źle odczytali intencje Platona i zniekształcili jego filozofię ${ }^{58}$. Przykładowo, zdaniem George'a Granta, drugorzędne w rozważaniach Platona elementy wysunął Popper na pierwszy plan. „Popper uważa, że głównym zainteresowaniem Platona jest zagadnienie środków w polityce. Powiedziałbym raczej, że główna kwestią jest dla Platona zagadnienie celów, których jego zdaniem człowiek nie odnajdzie w życiu politycznym" ${ }^{29}$. Ponieważ Popper nie zauważa, że Platon koncentruje się na zagadnieniu celu życia, rozważania o politycznych środkach mają jedynie charakter pomocniczy, jest skłonny oskarżyć Platona o historycyzm.

\footnotetext{
Tamże, s. 199.

Por. Platon, Państwo, 389 b,c, s. 87.

K. Popper, Społeczeństwo otwarte..., s. 178.

Tamże, s. 217.

Tamże, s. 225.

Por. J. Wild, Plato's Modern Enemies and the Theory of Natural Law, Chicago 1953; R. B. Levinson, In Defense of Plato, Cambridge 1953.

59 G. P. Grant, dz. cyt., s. 186.
} 
Według Johna Hallowella trudności związane ze zrozumieniem i interpretacją myśli Platona biorą się częściowo z tego, że „jego myśl nie może zostać zrozumiana czy adekwatnie opisana w kategoriach współczesnej terminologii politycznej" ${ }^{60}$. Rzuca się w oczy, na co chętnie zwracają uwagę krytycy Platona, że nie jest on liberalnym demokratą. Nie uznaje wolności za dobro ostateczne, nie uważa, że państwo powstaje, by ją gwarantować. Nie uznaje za słuszne, by władza rządziła we własnym interesie ${ }^{61}$. Jednak, podkreśla R. Sharples, Platon opowiada się nie tyle przeciw demokracji, co przeciw demokracji opartej na ignorancji ${ }^{62}$. Choć pytanie o to, czy Platon optował za despotyzmem, pozostaje otwarte, „nie ma wątpliwości, nawet dla większości przyjaciół Platona, że jego idealna wspólnota jest autorytarna zarówno w kwestii zasad, jak i praktyki. Najważniejsze jej instytucje mają taki kształt, że tylko nieliczni spośród zwolenników Platona byliby skłonni tolerować je we współczesnych państwach, w których żyją" ${ }^{63}$.

Niezaprzeczalną zasługą Poppera jest odbrązowienie Platona i rzucenie nowego światła na jego filozofię społeczną. Popper nie zawahał się określić stawianego na piedestale Platona jako „totalitarnego polityka partyjnego, któremu niezbyt się wiodło w bezpośrednich, praktycznych posunięciach, ale który odniósł aż nazbyt wielki sukces w długiej perspektywie $\mathrm{w}$ dziedzinie propagandy mającej na celu powstrzymanie i zniszczenie cywilizacji, której nienawidził" ${ }^{64}$ Nasuwa się jednak wątpliwość, czy składanie na barki Platona odpowiedzialności za dwudziestowieczny totalitaryzm nie było projektem aż nazbyt zuchwałym. Można mieć bowiem wrażenie, że trudna teraźniejszość, przez pryzmat której postrzegał Platona Popper, miała swój udział w tak krytycznej ocenie starożytnego filozofa. Chociaż zawarte w platońskim Państwie idee budzą dziś mieszane uczucia, trudno uznać totalitaryzm za ich odzwierciedlenie.

Popperowska interpretacja Platona po dziś dzień budzi kontrowersje. Można jednak przypuszczać, że Popper prawdopodobnie cieszyłby się z tych dyskusji i intelektualnych sporów. Krytykując ideał panującej pośród ludzi jednorodności opinii sam stwierdził bowiem, że ludzkie społeczeństwo bez konfliktów nie byłoby społeczeństwem przyjaciół, lecz mrówek ${ }^{65}$. Duch krytycznego myślenia był tym, czego Popper życzył sobie najbardziej. Odpowia-

60 J. H. Hallowell, Plato and His Critics, „The Journal of Politics”, vol. 27, no. 2, 1965, s. 275.

61 Tamże.

62 R. W. Sharples, Plato on Democracy and Expertise, „Greece \& Rome”, 2nd Ser., vol. 41, no. 1, 1994, s. 52.

63 Plato, Popper and Politics. Some Contributions to a Modern Controversy, R. Bambrough (ed.), Cambridge 1967, s. 10.

64 K. Popper, Spoleczeństwo otwarte..., s. 216.

65 K. Popper, Nieustanne poszukiwania..., s. 160. 
dając na zadane przez Kanta pytanie o to, czym jest Oświecenie, Popper określił je jako „wyjście z zawinionej przez człowieka niezdolności do korzystania z własnej inteligencji bez zewnętrznego nadzoru"66.

Popper uznawał, że gotowość do samodzielnego myślenia to podstawa społeczeństwa otwartego. Narzędziami wolności są bowiem: wiedza, samodzielne myślenie, kwestionowanie autorytetów, krytycyzm i samokrytycyzm $^{67}$. Tak więc nawet krytykując Poppera możemy obrać wytyczoną przez niego drogę do społeczeństwa otwartego. Nie jest ona łatwa - prowadzi w kierunku „nieznanego, niepewnego i niebezpiecznego”. Jednak alternatywą dla tego wysiłku jest zdaniem Poppera tylko zezwierzęcenie.

D O R O T A S T A S I A K

Tenże, In Search of a Better World, London-New York 1992, s. 128.

67 I. Jarvie, S. Pralong, dz. cyt., s. 4. 


\section{Karl Popper - footnotes to Plato once again}

The essay Karl Popper - footnotes to Plato once again deals with Popperian interpretation of Plato's political and social philosophy presented in The Open Society and Its Enemies - an influential two-volume work written in 1945. Popper, who regarded his work as a private contribution to the war, made an effort of reinterpreting Plato in order to provide an answer to the question about the origins of totalitarianism in the $20^{\text {th }}$ century. In his opinion, Plato's anti-democratism, followed by historicism of Hegel and Marx, contributed to a creation of the "closed" society.

Asking whether Popper's criticism of Plato has solid foundations, the author mentions the aspects of Platonic thought that cannot be reconciled with the liberal creed.

Having discussed the controversies concerning Plato's authoritarian inclinations, the author elaborates Popper's concept of the "open" society and the interpretation of Plato's alleged totalitarian ideas. Among the discredited aspects of Plato's philosophy, the author enumerates the organic nature of the state, total subordination of an individual to the good of his community, a class system with the hegemony of philosopher kings, Platonic theory of justice and ambitions of all-encompassing social engineering.

Moreover, certain attention is paid to the controversies surrounding The Open Society and Its Enemies and Popper's attack on Plato's authority. The possible limitations of equaling Plato's theory of the ideal state with modern totalitarian experiments are discussed. Finally, the author emphasises the fact that criticising Popper, in the light of his approval of critical thinking, can lead to the implementation of his vision of the open society. 